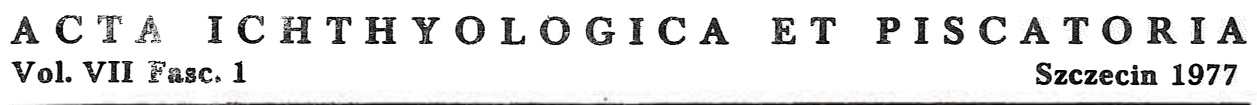

Barbara SZLAUER

$\underline{\text { Hydrobiology }}$

\title{
THE ZOOPLANKTON REMOVAL FROM LAKES BY THE RIVER PLONIA
}

\section{ZOOPLANKTON WYNOSZONY Z JEZIOR PRZEZ RZEKE PLONIE}

Department of Hydrozoology, Academy of Agriculture, Szczecin

The zooplankton species composition, abundance and biomass in places of the river Płonia's outflow from lakes were investigated. The zooplankton density and biomass were found to reach 2 million individuals $/ \mathrm{m}^{3}$ and $11 \mathrm{~g} / \mathrm{m}^{3}$, respectively. A number of seasonal phenomena as well as diurnal abundance fluctuations were found out. The zooplankton removed from lakes was quickly reducẹd in the river.

\section{INTRODUCTION}

The zooplankton workers unanimously state a paucity of the river zooplankton with respect to both its species composition and biomass (Siemińska, 1956; Cabejszak et al., 1956; Greze, 1957). Certain rivers, however, have their origin in lakes. If this is a case, the zooplankton removed from the lake can be encountered in a river. The literature dealing with zooplankton removed from lakes is very scarce and the views expressed contradict one another. In Woltereck's opinion (1908), planktonic animals usually are not carried away from a lake, while Odum (1963) states that lowland rivers do remove the zooplankton from lakes. Szlauer (1974) found even small streams to remove considerable numbers of animals from lakes.

The present paper was aimed at studying, as comprehensively as possible, the zooplankton of a river in a place adjoining its outflow from a lake.

\section{STUDY AREA AND METHODS}

The studies were carried out at two sites in the river Płonia (Northwestern Poland, Szczecin District). Site I was located $100 \mathrm{~m}$ off the lake Płoń, whereas Site II was placed 
$1500 \mathrm{~m}$ off the lake Żelewko, both sites occupying places where the river bed significantly narrowed beneath bridges. The water flow was calculated, the temperature measured, and quantitative plankton samples collected from 2001 of water using a 10-1 calibrated bucket and a No 25 bolting gauze plankton net. When counting the animals, the eggs were also taken into account; length of the individuals of each species was measured. The data thus obtained served to the zooplankton biomass computations. The tables by Kosova (1961) and, Cislenko's nommograms (1968) were mainly used in length - weight conversions. The biomass assessment was based on Hillbricht-Ilkowska and Patalas (1967).

The studies described above were carried out at Site I and II from October 1971 through October 1972 during the daytime. Additionally, the plankton was sampled at night at ca $1.5 \mathrm{hrs}$ and $3 \mathrm{hrs}$ after sunset at Site I and II, respectively.

The supplementary studies comprised:

1) diurnal plankton sampling in July and September 1972 at Site I at 4-hr intervals (using the above-described methods);

2) following the quantitative and qualitative changes in zooplankton in the river Płonia between the lakes Płon and Miedwie in August 1972;

3) one-time zooplankton studies with simultaneous thermal and chemical recordings in the lakes Płoń (July 19, 1972) and Żelewko (July 24, 1972).

\section{RESULTS}

Both the lakes Płoń and Żelewko as water bodies providing the river Płonia with plankton were taken into consideration when studying the latter. The lake Płon plankton (July 1972) was dominated by Cladocera and Copepoda, Bosmina coregoni coregoni and Chydorus sphaericus being the most abundant cladocerans. A mean density of animals as expressed in number of individuals per $\mathrm{m}^{3}$ of water was 1794690 , cladocerans, copepods (excl. nauplii) and rotators amounting to 661 250, 127500 , and 880620 ind.$/ \mathrm{m}^{3}$, respectively. In terms of biomass, cladocerans were also dominating, leaving copepods and rotifers behind; the respective biomass values were 8.404, 1.641, and $0.203 \mathrm{~g} / \mathrm{m}^{3}$. Daphnia longispina turned out to have produced the highest biomass amounting to $4.634 \mathrm{~g} / \mathrm{m}^{3}$. The total zooplankton biomass was $10.7 \mathrm{~g} / \mathrm{m}^{3}$. The vertical distribution of zooplankton showed a certain rarefaction of density within the near-bottom zone.

The Żelewko zooplankton (July 1972) markedly differed from that of the lake Płoń. The typical mid-lacustrine species were accompanied by considerable amounts of such littoral froms as Sida crystallina, Ceriodaphnia quadrangula, and Eucyclops sp. Rotifers and nauplii prevailed. A total number of 1328200 zooplankters was counted in $1 \mathrm{~m}^{3}$. The total Zelewko zooplankton biomass of $3.865 \mathrm{~g} / \mathrm{m}^{3}$ was 2.7 times lower than that found in the lake Płon $\left(10.7 \mathrm{~g} / \mathrm{m}^{3}\right)$.

Basing on classifications of lakes developed by Stangenberg (1936), Wiszniewski (1953), and Patalas (1954 b), the lake Płoń covering a 790-hectare area and of $4.5 \mathrm{~m}$ 
Table 1

The zooplankton species found in the river Płonia between September 15, 1971- October 20, 1972

\begin{tabular}{|c|c|c|c|}
\hline & \multirow{2}{*}{ Species } & \multicolumn{2}{|c|}{ Site } \\
\hline & & I & II \\
\hline Cladocera & $\begin{array}{l}\text { Sida crystallina O.F. Müller } \\
\text { Diaphanosoma brachyurum Lieven } \\
\text { Daphia longispina O.F. Müller } \\
\text { Daphnia cucullata G.O. Sars } \\
\text { Ceriodaphnia quadrangula O.F. Müller } \\
\text { Bosmina longirostris O.F. Müller } \\
\text { Bosmina coregoni crassicornis Lilljeborg } \\
\text { Bosmina coregoni coregoni Baird } \\
\text { Eury cercus lamellatus O.F. Müller } \\
\text { Acroperus harpae Baird } \\
\text { Alona costata G.O. Sars } \\
\text { Alona quadrangularis O.F. Müller } \\
\text { Alona affinis Leydig } \\
\text { Graptoleberis testudinaria Fischer } \\
\text { Chydorus sphaericus O.F. Müller } \\
\text { Polyphemus pediculus Linne } \\
\text { Leptodora kindtii Focke }\end{array}$ & $\begin{array}{l}\mathrm{x} \\
\mathrm{x} \\
\mathrm{x} \\
\mathrm{x} \\
\mathrm{x} \\
\mathrm{x}\end{array}$ & $\begin{array}{l}\mathrm{x} \\
\mathrm{x} \\
\mathrm{x} \\
\mathrm{x} \\
\mathrm{x} \\
\mathrm{x} \\
\mathrm{x} \\
\mathrm{x} \\
\mathrm{x} \\
\mathrm{x} \\
\mathrm{x} \\
\mathrm{x} \\
\mathrm{x} \\
\mathrm{x}\end{array}$ \\
\hline Copepoda & $\begin{array}{l}\text { Eudiaptomus gracilis G.O. Sars } \\
\text { Eudiaptomus graciloides Lilljeborg } \\
\text { Eucy clops lilljeborgi G.O. Sars } \\
\text { Cyclops vicinus Uljanin } \\
\text { Cyclops kolensis Lilljeborg } \\
\text { Megacyclops viridis Jurine } \\
\text { Diacyclops bicuspidatus Claus } \\
\text { Mesocyclops leuckarti Claus } \\
\text { Thermocyclops oithonoides G.O. Sars } \\
\text { Thermocyclops hyalinus Rehberg }\end{array}$ & $\begin{array}{l}\mathrm{x} \\
\mathrm{x} \\
\mathrm{x} \\
\mathrm{x} \\
\mathrm{x} \\
\mathrm{x}\end{array}$ & $\begin{array}{l}\mathrm{x} \\
\mathrm{x} \\
\mathrm{x} \\
\mathrm{x} \\
\mathrm{x} \\
\mathrm{x} \\
\mathrm{x} \\
\mathrm{x} \\
\mathrm{x} \\
\mathrm{x}\end{array}$ \\
\hline Rotatoria & $\begin{array}{l}\text { Trichocerca (Diurella) similis (Wierzejski) } \\
\text { Trichocerca capucina (Wierzejski et Zacharias) } \\
\text { Synchaeta pectinata Ehrenberg } \\
\text { Polyarthra Ehrenberg } \\
\text { Asplanchna priodonta Gosse } \\
\text { Euchlanis dilatata Ehrenberg } \\
\text { Brachionus caly ciflorus Pallas } \\
\text { Brachionus angularis Gosse } \\
\text { Keratella cochlearis (Gosse) } \\
\text { Keratella quadrata (Müller) } \\
\text { Kellicottia longispina (Kellicott) } \\
\text { Notholca squamula (Müller) } \\
\text { Notholca acuminata (Ehrenberg) } \\
\text { Filinia longiseta (Ehrenberg) } \\
\text { Rotatoria n.d. }\end{array}$ & $\begin{array}{l}x \\
x \\
x \\
x \\
x \\
x \\
x \\
x \\
x \\
x \\
x \\
x \\
x\end{array}$ & $\begin{array}{l}\mathrm{x} \\
\mathrm{x} \\
\mathrm{x} \\
\mathrm{x} \\
\mathrm{x} \\
\mathrm{x} \\
\mathrm{x} \\
\mathrm{x} \\
\mathrm{x} \\
\mathrm{x} \\
\mathrm{x} \\
\mathrm{x} \\
\mathrm{x} \\
\mathrm{x}\end{array}$ \\
\hline
\end{tabular}


maximum depth was ascribed to an advanced-eutrophication naturalpond type. On the other hand, the lake $\dot{Z}$ elewko (68 hectares, $6.5 \mathrm{~m}$ maximum depth) was difficult to ascribe to any of the limnologic types. This is a lake of a Characede-overgrown bottom, intensively fluxed by waters from the mesotrophic lake Miedwie.

The river Płonia (Site I) leaves the lake Płoń via an artificial soft-bottom channel devoid of any submerged vegetation. The maximum depth at Site I ranged within 0.49-0.89 m; the mean annual flow amounted to $1.579 \mathrm{~m}^{3} / \mathrm{sec}$. The river Płonia leaving the lake Żelewko (Site II) has a fairly fast current; the maximum depth range was $0.83-1.40 \mathrm{~m}$. The mean annual flow amounted to $2.51 \mathrm{~m}^{3} / \mathrm{s}$. In summertime the river was completely overgrown by macrovegetation disappearing in witner.

The temperature measurements recorded showed the water in the river Płonia behind Płon to cool faster in autumn and warm quicker in spring, higher temperatures being reached in summer as opposed to Site II.

The qualitative composition of the river Płonia zooplankton is summarized in Table 1. Times of occurrence and abundances of species listed in Table 1 are presented in Tables 2 and 3. As a supplement to the data comprised in Table 2 (Site I), it should be explained that the Daphnia group consists of two species here:Daphnia cucullata and D. longispina. The first was rather rare, found only in October, June and August with an August maximum density of 360000 ind./ $\mathrm{m}^{3}$. The other occurred as a "varietas" morphologically closest to the description of Daphnia longispina galeata G.O. Sars; a bluntly ended head in summer differed from the typical form. The entry "Bosmina" comprises data combined for Bosmina longirostris found only in May $1972\left(1600\right.$ ind. $\left./ \mathrm{m}^{3}\right)$ and Bosmina coregoni coregoni. The "other cladocerans" group encompassing Alona sp. and Leptodora kindti did not play any significant role in the plankton examined. The "Cyclops" group contained the biologically similar species: Cyclops kolensis and C. vicinus. Eucyclops lilljeborgi, Megacyclops viridis copepodites, Thermocyclops oithonoides and unidentified cyclopid copepodites were all placed in the "other Copepoda" group. The "other Rotatoria" comprise all the rotifer species listed in Table 1 (for Site I) except for Asplanchna, together with many species of naked rotifers.

The total abundance of zooplankters in the river Płonia behind the lake Płon is very impressing. During the period of maximum growth (August) 2035500 individuals were counted in $1 \mathrm{~m}^{3}$ of water. The other peak (802 500 ind. $/ \mathrm{m}^{3}$ ) occurred in April. Even during the March minimum there were still 75058 ind. $/ \mathrm{m}^{3}$.

The species predominating in a particular month are shown in Table 2. Having this aspect in mind, the animals were divided into two size groups: crustaceans and smaller animals (Rotatoria and nauplii). Among the crustaceans, Bosmina spp. were the most frequent dominants prevailing in October, November and December 1971, and in January 1972. Daphnia spp. predominated in May and September, while Chydorus sphaericus in August and October 1972. Eudiaptomus gracilis prevailed in February when the plankton was generally poor, while Masocyclops leuckarti was most abundant in June and July. Cyclops spp. were most numerous in April and "other Copepoda" in March. As to the smaller zooplankters, nauplii prevailed from September through January, the 
Abundance of zooplankton in river Płonia Site I (ind./ $\mathrm{m}^{3}$ );

mean diurnal numbers

\begin{tabular}{|c|c|c|c|c|c|c|c|c|c|c|c|c|c|}
\hline Date, Species & 15.X.71 & 29.XI.71 & 17.XII.71 & 14.I.72 & 17.II.72 & 16.III.72 & 15.IV.72 & 24.V.72 & 15.VI.72 & 19.VII.72 & 18.VIII.72 & 6.IX.72 & 20.X.72 \\
\hline Daphnia & 10000 & 7958 & 1688 & 2188 & 313 & 94 & 1250 & 2363375 & 16875 & 0 & 94500 & 20188 & 9250 \\
\hline Bosmina & 64375 & 22041 & 14000 & 6500 & 313 & 62 & 313 & 4025 & 25125 & 0 & 6000 & 375 & 4375 \\
\hline $\begin{array}{l}\text { Chydorus } \\
\text { sphaericus }\end{array}$ & 42000 & 1250 & 2563 & 0 & 0 & 0 & 1250 & 3075 & 2375 & 10813 & 505500 & 16875 & 60375 \\
\hline $\begin{array}{l}\text { Other } \\
\text { Cladocerans }\end{array}$ & 5745 & 542 & 0 & 0 & 250 & 31 & 313 & 700 & 2515 & 0 & 4500 & 0 & 0 \\
\hline $\begin{array}{l}\text { Eudiaptomus } \\
\text { gracilis }\end{array}$ & 4330 & 5166 & 5125 & 4188 & 6438 & 250 & 4688 & 4625 & 9500 & 1750 & 0 & 500 & 9500 \\
\hline $\begin{array}{l}\text { Mesocyclops } \\
\text { leuckarti }\end{array}$ & 14208 & 0 & 0 & 0 & 0 & 0 & 8750 & 5425 & 26625 & 30500 & 241707 & 2750 & 2750 \\
\hline Cyclops & 0 & 3374 & 2938 & 813 & 375 & 2937 & 13125 & 0 & 0 & 0 & 0 & 0 & 14000 \\
\hline $\begin{array}{l}\text { Qther } \\
\text { Copepoda }\end{array}$ & 1393 & 1084 & 0 & 625 & 14875 & 8594 & 1563 & 12775 & 20875 & 1188 & 19293 & 11552 & 18125 \\
\hline $\begin{array}{l}\text { Asplanchna } \\
\text { priodonta }\end{array}$ & 1580 & 10458 & 22000 & 151888 & 29313 & 7875 & 24688 & 225 & 16875 & 0 & 0 & 2125 & 375 \\
\hline $\begin{array}{l}\text { Other } \\
\text { Rotatoria }\end{array}$ & 98998 & 24750 & 43250 & 20938 & 100500 & 34748 & 386250 & 78900 & 81625 & 54875 & 718500 & 65375 & 101250 \\
\hline $\begin{array}{l}\text { Cladocera } \\
\text { total }\end{array}$ & 122120 & 31790 & 18250 & 8688 & 875 & 187 & 3125 & 244175 & 46890 & 10813 & 610500 & 37438 & 74000 \\
\hline $\begin{array}{l}\text { Copepoda } \\
\text { total }\end{array}$ & 19930 & 9623 & 8063 & 5625 & 21688 & 11780 & 28125 & 22825 & 57000 & 33438 & 261000 & 14802 & 44375 \\
\hline Nauplii & 43645 & 54667 & 98563 & 65063 & 82375 & 20469 & 360313 & 34850 & 66500 & 51375 & 445500 & 192563 & 196125 \\
\hline $\begin{array}{l}\text { Rotatoria } \\
\text { total }\end{array}$ & 100578 & 35208 & 65250 & 36125 & 129813 & 42623 & 410938 & 79125 & 98500 & 54875 & 718500 & 67500 & 101625 \\
\hline Grand total & 286237 & 131287 & 190125 & 115500 & 234750 & 75058 & 802500 & 380975 & 268890 & 150500 & 2035500 & 312302 & 416125 \\
\hline
\end{tabular}


Abundance of zooplankton in river Płonia Site II (ind./ $\mathrm{m}^{3}$ )

mean diurnal numbers

\begin{tabular}{|c|c|c|c|c|c|c|c|c|c|c|c|c|c|}
\hline Date & $15 \mathrm{X}$ & $29 \mathrm{XI}$ & 17 XII & $14 \mathrm{I}$ & 17 II & $16 \mathrm{III}$ & $15 \mathrm{IV}$ & $24 \mathrm{~V}$ & $15 \mathrm{VI}$ & 17 VII & $18 \mathrm{VIII}$ & $15 \mathrm{IX}$ & $20 X$ \\
\hline Species & \multicolumn{3}{|c|}{1971} & \multicolumn{10}{|c|}{1972} \\
\hline Bosmina & 2535 & 14060 & 1563 & 625 & 125 & 150 & 94 & 3000 & 30750 & 5375 & 6438 & 910 & 1200 \\
\hline $\begin{array}{l}\text { Ceriodaphnia } \\
\text { quadrangula }\end{array}$ & 1343 & 0 & 0 & 0 & 0 & 0 & 0 & 0 & 0 & 13125 & 5000 & 2063 & 275 \\
\hline $\begin{array}{l}\text { Other } \\
\text { Cladocera }\end{array}$ & 373 & 270 & 213 & 38 & 25 & 0 & 0 & 0 & 2250 & 2688 & 735 & 540 & 550 \\
\hline Eudiaptomus & 843 & 853 & 1338 & 788 & 275 & 300 & 1094 & 325 & 875 & 188 & 0 & 268 & 500 \\
\hline Thermocyclops & 813 & 1469 & 1875 & 0 & 0 & 350 & 4531 & 2208 & 56750 & 15013 & 1548 & 0 & 375 \\
\hline $\begin{array}{l}\text { Mesocyclops } \\
\text { leuckarti }\end{array}$ & 250 & 219 & 75 & 100 & 0 & 0 & 0 & 0 & 625 & 3288 & 1390 & 338 & 0 \\
\hline $\begin{array}{l}\text { Other } \\
\text { Copepoda }\end{array}$ & 1375 & 5145 & 9663 & 2075 & 1500 & 1850 & 6218 & 4083 & 1750 & 15313 & 7625 & 2013 & 500 \\
\hline $\begin{array}{l}\text { Asplanchna } \\
\text { priodonta }\end{array}$ & 8688 & 708 & 688 & 50 & 425 & 450 & 375 & 29208 & 14625 & 125 & 188 & 7388 & 1600 \\
\hline $\begin{array}{l}\text { Other } \\
\text { Rotatoria }\end{array}$ & 25985 & 35782 & 36800 & 11463 & 14950 & 23713 & 98562 & 228460 & 151750 & 43063 & 15063 & 25795 & 18200 \\
\hline $\begin{array}{l}\text { Cladocera } \\
\text { total }\end{array}$ & 4248 & 14330 & 1775 & 663 & 150 & 150 & 94 & 3000 & 33000 & 21188 & 12173 & 3513 & 2025 \\
\hline $\begin{array}{l}\text { Copepoda } \\
\text { total }\end{array}$ & 3280 & 7685 & 12950 & 2963 & 1775 & 2500 & 11843 & 6615 & 60000 & 33800 & 10563 & 2618 & 1375 \\
\hline Nauplius & 6248 & 5518 & 5738 & 1525 & 6050 & 6638 & 32344 & 31540 & 19750 & 53188 & 49938 & 11630 & 4375 \\
\hline $\begin{array}{l}\text { Rotatoria } \\
\text { total }\end{array}$ & 34673 & 36489 & 37488 & 11513 & 15375 & 24163 & 98938. & 257668 & 166375 & 43188 & 15250 & 33183 & 19800 \\
\hline Grand total & 48448 & 64021 & 57950 & 16663 & 23350 & 33450 & 143216 & 298823 & 279125 & 151363 & 87923 & 50943 & 27575 \\
\hline
\end{tabular}


remaining months shownig a domination of rotifers, a very slight one in February, April and July.

As a supplement to Table 3 (Site II), it should be added that under "Bosmina" the data concerning two morphologically similar species, Bosmina longirostris and B. coregoni crassicornis were placed. Eudiaptomus gracilis and E. graciloides were treated jointly as "Eudiaptomus". The data concerning "Thermocyclops" are mainly those for T. oithonoides; T. hyalinus was found only in July and August with a maximum density of $1074 \mathrm{ind} . \mathrm{m}^{3}$ in July. The "Other cladocerans" group played no significant part in the zooplankton studied. The "Other Copepoda" consisted of Megacyclops viridis, Diacyclops bicuspidatus, Cyclopskolensis, and C. vicinus.

In general, the zooplankters of the river Płonia behind the lake Żelewko (Site II) reached their maximum occurrence in May and June, the respective abundances being 298823 and 279125 ind./m³. During the January minimum, only 16603 animals were found to occur in $1 \mathrm{~m}^{3}$.

The dominating position was occupied by various species throughout the year (Table 3). Of the crustaceans, the most frequent dominant was the polyspecific group of "Other Copepoda" prevailing from January through May ad then in July, August and December. In December and March the group consisted exclusively of Cyclops kolensis and $C$. vicinus. In June, Thermocyclops oithonoides was a dominant crustacean. The remaining two months (October and November) showed the domination of Bosmina spp., while Ceriodaphnia sp. together with "Other Copepoda" were most abundant in September. Thus copepods were found to be by far the prevailing crustaceans in the zooplankton of the river Płonia beyond Żelewko throughout the year. In the other group of zooplankters (Rotatoria and nauplii), the rotifers were decidedly dominant during ten months, only July and August bringing nauplii up to the prevailing position (Table 3).

The age composition within a particular species' population and sizes of individuals varied throughout the year, which bore a considerable effect on the zooplankton biomass. These changes will be discussed taking a few crustacean species of Site I as examples. The population of Bosmina coregoni coregoni contained a very small proportion of young individuals, or was completely devoid of them, from November through April; in the summmer month, as a rule the young individuals prevailed. Young Daphnia longispina prevailed in the population almost every month, the greatest predominance (almost 40-fold) being observed in June. Also Mesocyclops leuckarti showed its copepodite stages permanently dominating over the adults, this domination being most pronounced in June and October. In Cyclops spp., the adults were most abundant from December through February, while the copepodites in spring and autumn.

Table 4 presents diurnal fluctuations in the zooplakton abundance at Site I in July 1972. The crustacean abundance diurnal variations are best observed in the last two columns of the table. The most numerous species, Chydorus sphaericus and Mesocyclops leuckarti, were the decisive factors in the geeral diurnal picture of occurrence of cladocerans and copepods. The nauplii and Rotatoria occurred more evenly when 
Zooplankton abundance (ind. $/ \mathrm{m}^{3}$ ) in river Płonia Site I at various times of day; July 19 and 20, 1972

\begin{tabular}{|c|c|c|c|c|c|c|c|c|}
\hline \multirow{3}{*}{ Species } & \multicolumn{3}{|c|}{ Day } & \multicolumn{3}{|c|}{ Night } & \multirow{2}{*}{\multicolumn{2}{|c|}{ Mean }} \\
\hline & \multicolumn{6}{|c|}{ hour } & & \\
\hline & $6^{00}$ & $12^{\circ 0}$ & $18^{\circ 0}$ & $22^{00}$ & $24^{\circ 0}$ & $2^{\circ 0}$ & day & night \\
\hline Daphnia longispina juv. & 0 & 500 & 0 & 0 & 0 & 500 & 166 & 166 \\
\hline Bosmina coregoni juv. & 250 & 250 & 0 & 0 & 0 & 0 & 166 & 0 \\
\hline Chydorus sphaericus juv. & 6000 & 18520 & 6625 & 7000 & 4000 & 6750 & 10292 & 5916 \\
\hline Chydorus sphaericus $\$$ & 4750 & 2250 & 2250 & 5750 & 3000 & 3750 & 3083 & 4166 \\
\hline Eudiaptomus gracilis cop. $\$,{ }^{\star}$ & 4250 & 2625 & 1000 & 2500 & 1000 & 750 & 2624 & 1416 \\
\hline Megacyclops viridis cop. & 500 & 375 & 125 & 2250 & 2750 & 2500 & 333 & 2500 \\
\hline Mesocyclops leuckarti cop. & 33500 & 13875 & 17000 & 32250 & 27750 & 42500 & 21458 & 34166 \\
\hline Mesocyclops leuckarti $\$,{ }^{\star}$ & 9500 & 1375 & 500 & 11250 & 4500 & 11750 & 3791 & 9166 \\
\hline Harpacticoida n. d. & 250 & 0 & 500 & 250 & 0 & 250 & 250 & 166 \\
\hline Cladocera total & 11000 & 21250 & 8875 & 12750 & 7000 & 11000 & 13708 & 10250 \\
\hline Copepoda total & 48000 & 18250 & 19125 & 48500 & 36000 & 57750 & 28458 & 47416 \\
\hline Nauplii total & 53000 & 56750 & 55750 & 47000 & 35250 & 48500 & 55167 & 43583 \\
\hline Rotatoria total & 49000 & 40250 & 47000 & 62750 & 52250 & 58000 & 45417 & 57667 \\
\hline Grand total & 161000 & 136500 & 130750 & 171000 & 130500 & 175250 & 142750 & 158917 \\
\hline
\end{tabular}


Seasonal changes in body length of zooplankters at Site I and II

(length in $\mathrm{mm}$ )

\begin{tabular}{|c|c|c|c|c|c|c|c|c|c|c|c|c|}
\hline \multirow{3}{*}{ Species $\quad{ }^{\text {rature }}\left({ }^{\circ} \mathrm{C}\right)$} & $\mathrm{x}$ & $\mathrm{XI}$ & XII & I & II & III & IV & $\mathrm{V}$ & VI & VII & VIII & IX \\
\hline & \multicolumn{3}{|c|}{1971} & \multicolumn{9}{|c|}{1972} \\
\hline & 10.8 & 2.8 & 4.7 & 0.0 & 1.5 & 3.0 & 9.2 & 17.0 & 17.3 & 22.2 & 19.4 & 15.5 \\
\hline Bosmina longirostris $q$ & 0.341 & 0.360 & 0.333 & 0.369 & 0.387 & - & - & 0.323 & 0.305 & 0.288 & 0.285 & 0.333 \\
\hline $\begin{array}{l}\text { Bosmina coregoni } \\
\text { crassicornis } \$\end{array}$ & 0.423 & 0.408 & 0.446 & 0.444 & 0.454 & 0.485 & 0.504 & 0.399 & $0.369^{-}$ & 0.355 & 0.387 & 0.445 \\
\hline $\begin{array}{l}\text { Bosmina coregoni } \\
\text { coregoni } q\end{array}$ & 0.514 & 0.509 & 0.535 & 0.548 & 0.569 & 0.603 & - & 0.499 & 0.484 & - & 0.487 & 0.483 \\
\hline Eudiaptomus gracilis $\$$ & 1.289 & 1.323 & 1.278 & 1.263 & 1.265 & 1.116 & 1.228 & 1.325 & 1.269 & - & 1.134 & - \\
\hline Eudiaptomus gracilis $\delta^{\star}$ & 1.182 & 1.192 & 1.156 & 1.162 & 1.199 & - & 1.207 & 1.179 & 1.215 & - & - & - \\
\hline Mesocyclops leuckarti $\subsetneq$ & 0.996 & - & - & - & - & - & 0.860 & 1.017 & 1.080 & 0.932 & 0.941 & 0.964 \\
\hline Mesocyclops leuckarti ${ }^{\star}$ & - & - & - & -- & - & - & 0.738 & 0.785 & 0.736 & 0.717 & 0.714 & 0.696 \\
\hline Keratella quadrata $q$ & 0.145 & 0.140 & 0.129 & 0.141 & 0.139 & 0.142 & 0.151 & 0.153 & 0.143 & 0.139 & 0.146 & 0.138 \\
\hline Keratella cochlearis $q$ & 0.095 & 0.097 & 0.101 & 0.104 & 0.108 & 0.107 & 0.103 & 0.098 & 0.091 & 0.087 & 0.083 & 0.086 \\
\hline
\end{tabular}


Biomass of river Płonia zooplankton at Site I (behind lake Płoń)

(wet weight in $\mathrm{g} / \mathrm{m}^{3}$ ); mean diurnal values

\begin{tabular}{|c|c|c|c|c|c|c|c|c|c|c|c|c|c|c|}
\hline Species Date & $15 \times 71$ & 29 XI 71 & 17 XII 71 & 14 I 72 & 17 II 72 & 16 III 72 & 15 IV 72 & $24 \mathrm{~V} 72$ & 15 VI 72 & 19 VII 72 & 18 VIII 72 & 6 IX 72 & $20 \times 72$ & $\begin{array}{c}\text { Annual } \\
\text { mean }\end{array}$ \\
\hline Daphnia & 0.078 & 0.257 & 0.055 & 0.103 & 0.008 & 0.002 & 0.107 & 3.850 & 0.279 & 0.0 & 3.198 & 0.820 & 0.358 & 0.701 \\
\hline Bosmina & 1.177 & 1.068 & 0.644 & 0.350 & 0.019 & 0.002 & 0.020 & 0.017 & 0.212 & 0.0 & 0.062 & 0.003 & 0.109 & 0.283 \\
\hline $\begin{array}{l}\text { Chydorus } \\
\text { sphaericus }\end{array}$ & 0.155 & 0.007 & 0.019 & 0.0 & 0.0 & 0.0 & 0.003 & 0.014 & 0.007 & 0.023 & 3.193 & 0.085 & 0.338 & 0.296 \\
\hline $\begin{array}{l}\text { Other } \\
\text { Cladocera }\end{array}$ & 0.115 & 0.018 & 0.0 & 0.0 & 0.004 & 0.002 & 0.006 & 0.008 & 0.125 & 0.0 & 0.675 & 0.0 & 0.0 & 0.073 \\
\hline Eudiaptomus & 0.120 & 0.114 & 0.132 & 0.194 & 0.306 & 0.005 & 0.151 & 0.155 & 0.353 & 0.021 & 0.0 & 0.006 & 0.364 & 0.148 \\
\hline $\begin{array}{l}\text { Mesocyclops } \\
\text { leuckarti }\end{array}$ & 0.248 & 0.0 & 0.0 & 0.0 & 0.0 & 0.0 & 0.123 & 0.109 & 0.358 & 0.239 & 3.431 & 0.037 & 0.047 & 0.353 \\
\hline Cyclops & 0.0 & 0.218 & 0.169 & 0.067 & 0.030 & 0.093 & 0.677 & 0.0 & 0.0 & 0.0 & 0.0 & 0.0 & 0.471 & 0.133 \\
\hline Other Copepoda & 0.13 & 0.722 & 0.0 & 0.006 & 0.149 & 0.086 & 0.015 & 0.219 & 0.524 & 0.043 & 0.251 & 0.083 & 0.191 & 0.123 \\
\hline Asplanchna & 0.098 & 0.240 & 0.506 & 0.304 & $0.469^{\circ}$ & 0.118 & 0.691 & 0.006 & 1.046 & 0.0 & 0.0 & 0.016 & 0.003 & 0.269 \\
\hline Other Rotatoria & 0.046 & 0.015 & 0.024 & 0.030 & 0.101 & 0.019 & 0.144 & 0.045 & 0.047 & 0.018 & 0.254 & 0.021 & 0.044 & 0.062 \\
\hline $\begin{array}{l}\text { Total } \\
\text { Cladocera }\end{array}$ & 1.526 & 1.351 & 0.718 & 0.453 & 0.030 & 0.006 & 0.137 & 3.890 & 0.624 & 0.023 & 7.129 & 0.907 & 0.805 & 1,354 \\
\hline $\begin{array}{l}\text { Total } \\
\text { Cpopepoda }\end{array}$ & 0.381 & 0.354 & 0.301 & 0.268 & 0.484 & 0.185 & 0.966 & 0.483 & 1.236 & 0.303 & 3.682 & 0.126 & 1.073 & 0.757 \\
\hline Nauplii & 0.039 & 0.037 & 0.065 & 0.215 & 0.338 & 0.075 & 1.237 & 0.027 & 0.215 & 0.074 & 0.223 & 0.098 & 0.670 & 0.255 \\
\hline $\begin{array}{l}\text { Rotatoria } \\
\text { total }\end{array}$ & 0.144 & 0.256 & 0.529 & 0.334 & 0.570 & 0.137 & 0.835 & 0.051 & 1.093 & 0.018 & 0.254 & 0.037 & 0.047 & 0.331 \\
\hline Grand total & 2.091 & 1.999 & 1.614 & 1.270 & 1.423 & 0.404 & 3.176 & 4.452 & 3.169 & 0.418 & 11.289 & 1.169 & 2.595 & 2.697 \\
\hline
\end{tabular}


compared to the crustaceans. The total abundance of the zooplankton as a whole showed no greater diurnal variation. The maximum density of $175250 \mathrm{ind} . / \mathrm{m}^{3}$ at 2 a.m. was only by $26 \%$ greater than the minimu m of 130500 ind. $/ \mathrm{m}^{3}$ at midnight.

The day- and nighttime sampling in every month gave an opportunity to follow the diurnal changes in the zooplankton over the year. The detailed data allowed some generalizations to be made. Cladocerans and copepods were found to occur at two sites mainly at night, for instance 7 and 8 times more Daphnia longispina occurred at Site I at night than during the daytime. This phenomenon was more clearly marked in summer, whereas in a cooler season and in winter the crustaceans often occurred more abundantly during the day, e.g., Daphnia longispina and Bosmina coregoni coregoni at Site I, and Bosmina longirostris and B.coregoni crassicornis at Site II. The other regularity is a generally more numerous occurrence of young cladocerans during the daytime than at night. As opposed to large crustaceans, small zooplankters (nauplii and Rotatoria) were present in more or less equal amounts during the day and at night all the year through.

In the course of the studies discussed, seasonal changes in body length were formed in the species of cladocerans, copepods and rotifers listed in Table 5 and inCeriodaphnia quadrangula, Thermocyclops oithonoides and Asplanchna priodonta. The data contained in the table are mean values derived from measurements of 20 mature individuals at least. The length of the body without spines was measured. Again the detailed data from Table 5 allow certain generalizations to be made, that is the zooplankters were showing the smallest size when the higher temperatures were prevailing and vice versa, the body sizes enlarged in cooler seasons of the year. All the cladocerans listed, Thermocyclops oithonoides and Kuratella cochlearis fully conformed to this rule as opposed to Eudiaptomus sp. and Mesocyclops sp. The differences between the extremal sizes in the same species were found to be small. It should be borne in mind, however, that these differences in length correspond to much greater differences in body weights and thus are definitely reflected in the zooplankton biomass.

The river Płonia zooplankton biomass expressed as $g$ wet weight $/ \mathrm{m}^{3}$ is summarized in Tables 6 and 7. The biomass at Site I was made up mainly by crustaceans, particularly Daphnia spp., Bosmina spp., Chydorus spp. and the copepod Mesocyclops leuckarti (Table 6). Mean biomasses of these, derived from the year-round data amounted to 0.701 , $0.283,0.296$, and $0.353 \mathrm{~g} / \mathrm{m}^{3}$, respectively. The biomass, of rotifers was lower, amounting in everage to $0.331 \mathrm{~g} / \mathrm{m}^{3}$, the grestest share of which $\left(0.269 \mathrm{~g} / \mathrm{m}^{3}\right)$ being contributed by the largest of the species, Asplanchna sp. The highest and lowest zooplankton biomasses were recorded in August and March, respectively, with the respective values of 11.289 and $0.404 \mathrm{~g} / \mathrm{m}^{3}$. Apart from seasonal fluctuations of biomass, also the diurnal ones were noted. The latter resulted to a large extent from the diurnal abundance fluctuations of the species present.

The zooplankton biomass in the river Płonia beyond the lake Z elewko was much lower than that recorded at Site I (Table 7). Even in its peak observed in May and June, the total biomass did not exceed $1 \mathrm{~g} / \mathrm{m}^{3}$. 
Biomass of river Płonia zooplankton at Site II (behind lake Żelewko)

(wet weight in $\mathrm{g} / \mathrm{m}^{3}$ ); mean diurnal values

\begin{tabular}{|c|c|c|c|c|c|c|c|c|c|c|c|c|c|c|}
\hline Date & $15 X$ & $29 \mathrm{XI}$ & $17 \mathrm{XII}$ & $14 \mathrm{I}$ & $17 \mathrm{II}$ & $16 \mathrm{III}$ & $15 \mathrm{IV}$ & $24 \mathrm{~V}$ & $15 \mathrm{IV}$ & $17 \mathrm{VII}$ & $18 \mathrm{VIII}$ & $15 \mathrm{IX}$ & $20 X$ & \multirow{3}{*}{$\begin{array}{c}\begin{array}{c}\text { Sirednia } \\
\text { roczna }\end{array} \\
0.019\end{array}$} \\
\hline Species & \multicolumn{3}{|c|}{1971} & \multicolumn{10}{|c|}{1972} & \\
\hline Bosmina & 0.011 & 0.071 & 0.008 & 0.007 & 0.001 & 0.002 & 0.002 & 0.012 & 0.098 & 0.010 & 0.010 & 0.002 & 0.008 & \\
\hline $\begin{array}{l}\text { Ceriodaphnia } \\
\text { quadrangula }\end{array}$ & 0.011 & 0.0 & 0.0 & 0.0 & 0.0 & 0.0 & 0.0 & 0.0 & 0.0 & 0.043 & 0.013 & 0.006 & 0.003 & 0.006 \\
\hline Other Cladocera & 0.009 & 0.001 & 0.003 & 0.001 & 0.001 & 0.0 & 0.0 & 0.0 & 0.022 & 0.091 & 0.006 & 0.002 & 0.006 & 0.011 \\
\hline Eudiaptomus & 0.015 & 0.018 & 0.029 & 0.022 & 0.006 & 0.010 & 0.028 & 0.011 & 0.026 & 0.009 & 0.0 & 0.005 & 0.010 & 0.015 \\
\hline Thermocyclops & 0.008 & 0.007 & 0.009 & 0.0 & 0.0 & 0.004 & 0.045 & 0.031 & 0.571 & 0.159 & 0.015 & 0.0 & 0.004 & 0.066 \\
\hline $\begin{array}{l}\text { Mesocyclops } \\
\text { leuckarti }\end{array}$ & 0.004 & 0.002 & 0.001 & 0.001 & 0.0 & 0.0 & 0.0 & 0.0 & 0.006 & 0.052 & 0.014 & 0.004 & 0.0 & 0.006 \\
\hline Other Copepoda & 0.014 & 0.087 & 0.164 & 0.010 & 0.007 & 0.023 & 0.081 & 0.051 & 0.025 & 0.171 & 0.038 & 0.010 & 0.003 & 0.053 \\
\hline Asplanchna & 0.071 & 0.008 & 0.011 & 0.001 & 0.006 & 0.006 & 0.007 & 0.496 & 0.183 & 0.001 & 0.002 & 0.052 & 0.014 & 0.066 \\
\hline Other Rotatoria & 0.016 & 0.058 & 0.038 & 0.025 & 0.027 & 0.046 & 0.133 & 0.203 & 0.049 & 0.017 & 0.014 & 0.022 & 0.014 & 0.051 \\
\hline $\begin{array}{l}\text { Cladocera } \\
\text { total }\end{array}$ & 0.031 & 0.073 & 0.011 & 0.008 & 0.002 & 0.002 & 0.002 & 0.012 & 0.120 & 0.145 & 0.030 & 0.011 & 0.018 & 0.036 \\
\hline $\begin{array}{l}\text { Copepoda } \\
\text { total }\end{array}$ & 0.041 & 0.115 & 0.203 & 0.032 & 0.014 & 0.036 & 0.155 & 0.093 & 0.624 & 0.390 & 0.067 & 0.019 & 0.017 & 0.140 \\
\hline Nauplii & 0.004 & 0.005 & 0.004 & 0.005 & 0.021 & 0.025 & 0.114 & 0.025 & 0.016 & 0.035 & 0.027 & 0.011 & 0.004 & 0.023 \\
\hline $\begin{array}{l}\text { Rotatoria } \\
\text { total }\end{array}$ & 0.088 & 0.066 & 0.049 & 0.026 & 0.033 & 0.052 & 0.140 & 0.700 & 0.232 & 0.019 & 0.017 & 0.074 & 0.029 & 0.117 \\
\hline Grand total & 0.164 & 0.259 & 0.268 & 0.074 & 0.070 & 0.115 & 0.412 & 0.833 & 0.998 & 0.596 & 0.141 & 0.117 & 0.068 & 0.316 \\
\hline
\end{tabular}


Zooplankton of river Płonia between lakes Płoń and Miedwie on August 30, 1972

(Distances between Sites I, II, III, and IV and lake Płoń: 0.1, 5, 8 and $10 \mathrm{~km}$, respectively)

\begin{tabular}{|c|c|c|c|c|c|c|c|c|c|}
\hline \multirow{2}{*}{ Species } & & \multicolumn{4}{|c|}{ Number of individuals per $1 \mathrm{~m}^{3}$ at sites } & \multicolumn{4}{|c|}{ Biomass in $\mathrm{g} / \mathrm{m}^{3}$ at sites } \\
\hline & & I & II & III & TV & I & II & III & IV \\
\hline $\begin{array}{l}\text { Daphnia } \\
\text { longispina }\end{array}$ & $\begin{array}{l}\text { juv } \\
\text { o }\end{array}$ & $\begin{array}{l}750 \\
750\end{array}$ & $\begin{array}{l}500 \\
500\end{array}$ & $\begin{array}{l}0 \\
0\end{array}$ & $\begin{array}{r}335 \\
0\end{array}$ & 0.060 & 0.041 & 0.0 & 0.005 \\
\hline $\begin{array}{l}\text { Daphnia } \\
\text { cucullata }\end{array}$ & $\begin{array}{l}\text { juv } \\
\text { \& } \delta^{0}\end{array}$ & $\begin{array}{r}32250 \\
1500\end{array}$ & $\begin{array}{r}15000 \\
500\end{array}$ & $\begin{array}{r}1250 \\
0\end{array}$ & $\begin{array}{r}335 \\
0\end{array}$ & 0.253 & 0.122 & 0.007 & 0.002 \\
\hline $\begin{array}{l}\text { Chydorus } \\
\text { sphaericus }\end{array}$ & $\begin{array}{l}\text { juv } \\
\text { q }\end{array}$ & $\begin{array}{l}13500 \\
28500\end{array}$ & $\begin{array}{l}22500 \\
52500\end{array}$ & $\begin{array}{l}10750 \\
23250\end{array}$ & $\begin{array}{l}14650 \\
15815\end{array}$ & 0.300 & 0.541 & 0.242 & 0.187 \\
\hline Other Cladocera & & 3000 & 0 & 0 & 165 & 0.017 & 0.0 & 0.0 & 0.001 \\
\hline $\begin{array}{l}\text { Mesocyclops } \\
\text { leuckarti }\end{array}$ & $\begin{array}{l}\text { cop. } \\
\text { o. } 0\end{array}$ & $\begin{array}{l}36750 \\
12000\end{array}$ & $\begin{array}{l}8500 \\
9000\end{array}$ & $\begin{array}{l}500 \\
250\end{array}$ & $\begin{array}{r}0 \\
830\end{array}$ & 0.744 & 0.367 & 0.009 & 0.025 \\
\hline Nauplii & & 420000 & 21500 & 3500 & 830 & 0.216 & 0.011 & 0.002 & 0.0004 \\
\hline Asplanchna priodonta & & 16500 & 2000 & 250 & 0 & 0.247 & 0.030 & 0.004 & 0.0 \\
\hline Other Rotatoria & & 62250 & 33500 & 33500 & 29530 & 0.027 & 0.010 & 0.011 & 0.009 \\
\hline $\begin{array}{l}\text { Cladocera total } \\
\text { (Chydorus sp. excl.) }\end{array}$ & & 38250 & 16500 & 1250 & 835 & 0.331 & 0.163 & 0.007 & 0.008 \\
\hline Total Rotatoria & & 81750 & 35500 & 33750 & 29530 & 0.275 & 0.040 & 0.015 & 0.009 \\
\hline Grand total & & 630750 & 166000 & 73250 & 62490 & 1.865 & 1.136 & 0.279 & 0.237 \\
\hline
\end{tabular}


Table 8 answers the question of the fate of zooplankton removed from the lake Płon. The changes occurring in this plankton were studied at Sites I-IV located at respective distances of $0.1,5,8$, and $10 \mathrm{~km}$ from the lake Płon. The last site (IV) was situated a several hundred metres off the lake Miedwie. The table sthows the zooplankton abundance and biomass to fall with the distance from the "sciurce", i.e., the lake Płon. The zooplankton abundance diminished 10 times over the $10-\mathrm{km}$ section of the river, the biomass decressing 8 times. Various factors jointly contributed to this general picture of the zooplankton decrease. The attention should be paid to a quick reduction in the crustaceans' abundance. Their numbers were much smaller at Site II, and a complete lack occurred sometimes at Sites III and IV. The above findings did not concern the cladocerans Chydorus sphaericus; no clear decrease was found in this species' abundance. A very low decrease was also recorded in numbers of minute rotifers contaied in "Other Rotatoria". It should be emphasized, however, that the abundance of the largest rotifers, Asplanchna sp., was falling as fast as that of most crustaceans.

\section{DISCUSSION}

The zooplankton of the river Płonia, studied at the sites beyond the lakes Płon and Żelewko, differed in many respects. The plankton removed from Żelewkowas richer as far as the number of species is concerned. 24 crustacean and 14 rotifer species were recorded here against 17 crustacean and 13 rotifer species observed in the river zooplankton beyound the lake Płoń. No forms typical of lakes, like Diaphanosoma brachyurum and Leptodora kindti present at Site I, were found beyond Żelewko (Site II); 6 typically littoral species (Sida crystallina, Ceriodaphnia quadrangula, Acroperus harpae, Alona costata, Graptoleberis testudinaria, Polyphemus pediculus) absent from Site I were recorded instead. The list of the copepods was richer at Site II by Eudiaptomus graciloides, Diacyclops bicuspidatus and Thermocyclops hyalinus. The smallest quantitative differences were observed in Rotatoria (Table 1). Also different species predominated at each site. In various months at Site I, the dominating position was occupied by: Bosmina coregoni coregoni, Daphnia longispina, Chydorus sphaericus, Mesocyclops leuckarti, Eudiaptomus gracilis, Cyclops spp., while at Site II usually the copepods Thermocyclops oithonoides and Cyclops spp., prevailed. Further differences between the sites are observed in times of presence and vanishing of certain species; for instance Mesocyclops leuckarti appeared at Site I two months earlier than at Site II and disappeared earlier. The stocks of zooplankton as measured by its abundance and biomass were completely different at the two sites. Much more planktonic organisms were found ot occur in the river Płonia beyond Płoń. The summarized entries in Tables 2 and 3 clearly point out to these differences; from the figures given the mean annual abundances of cladocerans, copepods, nauplii, rotifers, and total zooplankton at Site I can be calculated: $92989,41406,131639,149282$, and 415370 ind./ $\mathrm{m}^{3}$, respectively. In the river Płonia beyond the lake Żelewko (Site II) the respective mean abundances were: $7408,12151,18037,61086$, and 98681 ind. $/ \mathrm{m}^{3}$. Thus the number of 
cladocerans at Site I exceeded those at Site II thirteen. times, copepods - there times, nauplii - seven times, rotifers - two times, and the zooplankton in general was four times more abundant. Still greater differences were found in biomasses at the two sites. The mean annual biomass of the zooplankton at Site I was $2.697 \mathrm{~g} / \mathrm{m}^{3}$, while only 0.316 were found at Site II. It must be stressed that at Site I mostly crustaceans, mainly the cladocerans, contributed to the total biomass, whereas the copepods and rotifers were the major contributors at Site II.

A different composition of the zooplankton at both sites could be accounted for mainly by different limnologic nature of the lakesPłon and Żelewko, which stocked the river Płonia with zooplankton. The differences in abundances and biomasses of the zooplankton at the sites studied should be attributed to the resources of plankton in both lakes. The lake Żelewko zooplankton was poorer, particularly its biomass was low in comparison with that in lake Płon (3.8 and $10.7 \mathrm{~g} / \mathrm{m}^{3}$, respectively; the July data). The other cause for the less abundant occurrence of zooplankton at Site II could be found in fish and invertebrate predation within the $1-\mathrm{km}$ long section of the river before the Site. Iarge shoals of planktophagous bleak and young cyprinids were found to dwell there.

The plankton of the river Płonia, sampled at Sites I and II, is considered here as a river plankton. It would be hard to believe, however, that the character of the Site I plankton underwent a transformation during its four minutes' stay in a river after it had left the lake. On the contrary, it was all the time directly influenced by the lake. Therefore, basing on commonly known phenomena taking place in the lake itself, a number of events observed in the Płonia plankton at Site I can be explained. The seasonal succession of species, observed in Płonia, fully reflects the seasonal changes taking place in the lake Płon plankton. The changes result from the occurrence of warm- and cold-water zooplankton species in the lake. The first disappear from the plankton in autumn remaining in anabiosis to regain their activity next spring. The other are active during the cold season, the summer months being spent in the state of anabiosis. Some deviations from these regularities can be encountered, e.g., a warm-water species over-wintering in an active state. This was found in Płonia at Site I. Large amounts of warm-water cladocerans, Bosmina coregoni coregoni and Daphnia longispina (Table 2) occurred in winter. A particularly abundant occurrence of Bosmina coregoni coregoni at the beginning of winter could be explained by the species' maximum in late autumn (November). Therefore a very numerous population was over-wintering. The cladocerans remaining in winter were found to reproduce at a very slow rate as evidenced by sparse eggs and small numbers of young individuals, especially in B. coregoni coregoni. The cladoceran occurrence in winter is quoted in the literature (Szlauer and Widuto, 1966). Green (1961) attributed their slow reproduction to low temperatures prevailing at that time. The retarded reproduction results in the cladoceran population being reduced, which was observed in the river Płonia in Daphnia longispina and Bosmina coregoni coregoni towards the end of winter. 
Two peaks of abundance are typical of lacustrine planktonic crustaceans. The first usually occurs in spring and the other at the end of summer as well as in early autumn. The river Płonia plankton at Site I closely follows these regularities; the two peaks were found in Daphnia longispina, Bosmina coregoni coregoni, Chydorus sphaericus, Eudiaptomus gracilis,nauplii, Rotatoria, as well as in the zooplankton as a whole.

Seasonal changes in body size noted in the planktonic animals of the river Płonia as well as other phenomena observed here are not typical of a river; this kind of cyclic changes is specific for the lacustrine zooplankton (Hutchinson, 1967). An increase in sizes of many warm-water species was noteworthy because of its occurrence during a developmental depression of these species in the cold season. A retardation in metabolism and reproduction as well as a life-span prolongation are a few of possible reasons for that (Allee et al., 1958; Green, 1961).

At Site II in the river Płonia behind the lake Żelewko, a number of phenomena similar to those in lakes were observed too.

The above consideration underline many convergencies between the lacustrine plankton and that of the outflowing river. A question arises then whether the outflowing plakton can be regarded as identical with that of the lake. The studies presented cannot offer any definite answer though, because no systematic comparison of the river and lake was made. Such a comparison was carried out only once. On July 19, 1972, plankton samples were taken from the lake Płon and from Site I in the river Płonia.No Daphnia longispina, Bosmina coregoni coregoni, or Leptodora kindti were found in the outflowing river, whereas the species listed were abundant in the lake, e.g., numbers of $B$. coregon $i$ coregoni, Daphnia longispina, and L. kindti were 276250,590350 , and 600 individuals $/ \mathrm{m}^{3}$, respectively. Different species were dominant in the samples: Chydorus sphaericus with Bosmina coregoni coregoni as a sub-dominant were prevailing in the lake, while Mesocyclops leuckarti and Ch. sphaericus in the river. The Rotatoria/nauplii ratios were also different for the lacustrine and river plankton. It should be added here that the day of July 19, 1972 was an exceptional one because of the highest water temperature recorded for the river, the lowest flow and the slowest current, the respective values being $27^{\circ} \mathrm{C}, 0.947 \mathrm{~m}^{3} / \mathrm{sec}$. and $0.576 \mathrm{~m} / \mathrm{sec}$. Presumably these factors were decisive for the lack of removal of the cladoceran species listed from the lake. The comparative studies described indicate the necessity of certain precautions to be taken when interpreting an occurrence of a particular species in a river. Not always the absence of a species from an outflow corresponds to the species' absence from the lake.

The patterns of diurnal changes in the river Płonia plankton, outlined in the present paper, were not always equally clear. Many irregularities were found. The causes of the diurnal changes in the river should be looked for in the vertical distribution in the lake and in the vertical migrations of the zooplankton. The published papers concerning this subject state that adult crustaceans dwell in deeper layers of the lake at the daytime, while in the evening they ascend to the surface zone and remain there during the night (Patalas, 1954 a). Young crustaceans (except for the youngest larval stages) exhibit a 
similar distribution, occurring above the adults at the daytime (Szlauer, 1963). Such distribution of the crustacean zooplankton in the lake accounts for the observed diurnal changes in the plankton of the outflowing river, assuming that the outflow collects the surface layer of the lake. However, fairly often adult crustaceans were found in Płonia during the day. Such a situation is natural in the river outflowing from the lakes Płon and Żelewko. Both lakes are very shallow water bodies of a gently-sloping bottom, with no deep layers that could be a crustacean refuge in the daytime as it is the case in deeper lakes. Thus the river Płonia could collect plankton both from the surface and bottom, layers Profound effects of wind (mixing) on the plankton removed by the river should be taken into account as well. A more intensive removal of crustaceans during the daytime, observed in autumn and winter in Daphnia longispina and Bosmina coregoni coregoni of Site I as well as in Bosmina longirostris and B. coregoni crassicornis of Site II is more difficult to explain. The explanation should be sought again in the vertical distribution of these crustaceans in the lake. Presumably these warm-water forms tended to inhabit the upper layers of water during the day and thus large numbers of them were subject to removal by the river.

In order to obtain a relative estimation of the river Płonia planktonic resources, they were compared to those found in other water bodies. As related to Site I with the zooplankton abundance and biomass ranging within $2035500-75058 \mathrm{ind} . / \mathrm{m}^{3}$ 11.289-0.404 g/ $\mathrm{m}^{3}$, respectively, these values for other water bodies were as follows: Petrović (1954) computed biomasses for oligo-, meso-, and eutrophic lakes to amount to $0.62,1.96$, and $3.86 \mathrm{~g} / \mathrm{m}^{3}$, respectively. According to Pečen (1965), in deep, very transparent lakes of mean summer water temperatures of $17^{\circ} \mathrm{C}$, the summer żooplankton biomass amounts to $0.4 \mathrm{~g} / \mathrm{m}^{3}$, whereas it reaches $4 \mathrm{~g} / \mathrm{m}^{3}$ in sumpier in lakes of poor transparency and high summer temperatures $\left(22^{\circ} \mathrm{C}\right)$. Petrović (1968) found various zooplankton biomasses in lakes, depending on their trophic character. His data for the vegetative period of mesotrophic, eutrophic and intermediate-type lakes are as follows: $1.35,4.75$, and $3.74 \mathrm{~g}$ of zooplankton $/ \mathrm{m}^{3}$, respectively'. The winter biomasses were 2-3 and 20-30 times lower in meso- and eutrophic lakes, respectively. Greze (1957) gives the value of $0.035 \mathrm{~g} / \mathrm{m}^{3}$ as a biomass of zooplankton of the lower Yenisey. Cabejszak et.al. (1956) described the river Bug plankton as quantitatively poor, 11000 123000 ind. $/ \mathrm{m}^{3}$ being found in June. In the reservoirs of rivers $\mathrm{Ob}$ and Irtysh, Salazkin and Ustielenceva (1965) found the biomass range of $0.07-14.0 \mathrm{~g} / \mathrm{m}^{3}$ depending on the flow rate. Against this backgłound, the planktonic resources of the river Płonia Site I should be estimated as high. They exceed many rivers and lakes in this respect ani equal to water bodies of a pond type, very rich in plankton.

It should be stressed however, that the zooplankton rich in numbers and species occurred only in places just behind the lakes, which would be regarded as points against the length of the river. Site I contained presumably the richest zooplankton stock in the whole river. Such plankton-rich places occur certainly in other rivers flowing through lakes and can be easily overlooked when studying the rivers. This is why the zooplankton 
of rivers is commonly, and basically with a certain degree of justification, regarded as poor.

The example of Płonia indicates to a quick degradation of lacustrine zooplankton after it has got to non-typical environmental conditions of a river. This very abundant and highbiomass zooplankton of a large variety of species leaving the lake Płon (Site I) was transformed into a poor one consisting essentially of minute rotifers and the smallest cladoceran, Chydorus sphaericus. Its composition is similar to that found in ponds where a strong feeding stress of fishes is felt (Grygierek, 1965). These changes were caused mainly by grazing of young cyprinids occurring in masses in the studied part of the river and feeding on the zooplankton carried in. A part of the zooplankton could have been consumed by invertebrates living in the river and/or died out due to some abiotic factors' influence.

\section{REFERENCES}

Allee W.C., Emerson A.E. i inni, 1958. Elements of animal ecology. 1, PWN, Warszawa.

Cabejszek L., Malanowski Z., Włodek S., 1956 Plankton of River Bug. Pol. Archiw. Hydrobiol. 3: 189-202.

Cislenko L.,L., 1968. Nomogrammy dla opredelenija vesa vodnych organizmov po razmeram i forme tela. Izdatel'stwo "Nauka", Leningrad.

Green J., 1961. A Biology of Crustacea. Quadrangle books, Chicago.

Greze V.N., 1957. Kormovye resursy ryb reki Eniseja i ich ispol'zovanie. Izv. Vses. n.-i. in-ta ozern. i rec̀n. ch-va, 41: 3-234.

Grygierek E., 1965. Influence of fish upon planktonic crustacean fauna (second stage of studies). Roczn. Nauk rol. ser. B, 86, 2.

Hilbricht-Ilkowska A., Patalas K., 1967. Methods for estimation of production and biomass and some problems in quantitative zooplankton studies. Ekol. Pol. ser. B, 13: 139-172.

Hutchinson G.E., 1967. A treatise on Limnology. Vol. 2, Introduction to lake biology and the limnoplankton. John Wiley a Sons, N. York.

Kosova A.A., 1961. Vyčislenie vesa nekotorych form zoplanktona nizoviev Delty Volgi. Trudy astrach. gos. Zapov., 5: 151-159.

Odum E.P., 1963. Principles of ecology. Państw. Wyd. Rol. i Leśne, Warszawa.

Patalas K., 1954 a. Quantitative studies on diel and seasonal changes in pelagic crustacean distribution. Pol. Arch. Hydrobiol., 2: 31-155.

Patalas K., 1954 b. Pèlagic crustacean communities of 28 Pomeranian lakes. Ekol. Pol., 2, 1: 61-92.

Pec̀en G.A., 1965. Produkcja vetvistousych rakoobraznych ozernogo zooplanktona. Gidrobiol. Ż. 1: 19-26.

Petrovi X P.G., 1954. Koli estvennoe razvitie i raspredelenie zooplanktona v ozerach zapadnych oblastej BSSR. UČenye Zapiski, 17, ser. biol.: 38-71.

Petrovið P.G., 1968. Biomasa i produkcja zooplanktona roznotipnych ozer Narơ̌, Miastro i Batorino po mnogoletnim nabludenijam. (Metody opredelenija produkcji vodnych żivotnych, red. Vinberg G.G.), Minsk, Vysšaja Š̀kola: 173-183.

Salazkin A.A., Ustelenceva E.P., 1965. Zooplankton pojmiennych vodoemov niżnej Obi i nizov'ev Irtysza i nekotorye osobennosti ego rozvitija. Zool. $\dot{Z} .44: 818-825$.

Siemińska J., 1956. Hydrobiological and fishing description of River Brynica. Pol. Arch. Hydrobiol., 3: 69-160. 
Stangenberg M., 1936. Limnologic study against hydrochemical regime of Suwałki Lake District. Rozpr. Inst. Badaw. Lasów Państw., A. 19, Warszawa.

Szlauer L., 1963. The speed of the movements of plankton Crustacea as a factor: influencing the vertical stratification of juvenile and adult individuals. Pol. Arch. Hydrobiol., 11: 5-15.

Szlauer L., 1974. The use of zooplankton outflowing from lakes as food for young Coregonus lavaretus (Linnaeus, 1758). Roczn. Nauk rol., ser H, 96: 89-107.

Szlauer L., Widuto J., 1966. The crustacean plankton in the Sukiel Lake in the years 1955-1957. Zesz. Nauk WSR w Olsztynie, 21: 733-755.

Wiszniewski J., 1953. Remarks on typology of lakes. Pol. Arch. Hydrobiol. 1.

Woltereck R., 1908. Notiz über Plankton und Seeausflus. Int. Rev. d. Ges. Hydrobiol. u. Hydrograf., 1: $303-304$.

Translated: mgr Teresa Radziejewska

\section{ZOOPLANKTON WYNOSZONY Z JEZIOR PRZEZ RZEKĘ PŁONIĘ}

\section{Streszczenie}

W latach 1971-1972 badano zooplankton rzeki Płoni tuż za miejscem jej wypływania z jez. Płoń - stanowisko I oraz za jez. Żelewko - stanowisko II. Liczebność zooplanktonu na st. I była średnio czterokrotnie wyższa, a biomasa - dzięsięciokrotnie wyższa, w porównaniu ze stanowiskiem II. Inny też był skład gatunkowy i układ dominantów na obu stanowiskach (tab. 2 i 3 ).

Do gatunków najliczniej występujących w obrębie skorupiaków na st. I należały: Daphnia longispina (maksimum w maju 236375 osobn。 $/ \mathrm{m}^{3}$ ), Bosmina coregoni coregoni (maks. w październiku 64375 osobn. $/ \mathrm{m}^{3}$ ), Chydorus sphaericus (maks. w sierpniu $505500 \mathrm{osobn} . / \mathrm{m}^{3}$ ), Eudiaptomus gracilis (maks. w czerwcu i październiku po 9500 osobn. $/ \mathrm{m}^{3}$ ), Mesocyclops leuckarti (maks. w sierpniu 241700 osobn. $/ \mathrm{m}^{3}$ ), Cyclops (maks. w październiku i kwietniu po około 14000 osobn. $/ \mathrm{m}^{3}$ ). Ogólne maksimum zooplanktonu przypadło tu w sierpniu (2035 500 osobn. $/ \mathrm{m}^{3}$, tab. 2).

Najwię kszą biomasę tworzyły na stanowisku I wioślarki z rodzaju Daphnia, Bosmina, Chydorus oraz widłonóg - Mesocyclops leuckarti. Najwyższą biomasę $\left(11,289 \mathrm{~g} / \mathrm{m}^{3}\right)$ tworzył zooplankton w miesiącu sierpniu, minimum $\left(0,404 \mathrm{~g} / \mathrm{m}^{3}\right)$ przypadło na marzec, średnioroczna biomasa wyniosła $2,697 \mathrm{~g} / \mathrm{m}^{3}$ wody (tab. 6).

Stwierdzono sezonowe zmiany wymiarów u gatunków: Bosmina coregoni coregoni, Eudiaptomus gracilis, Mesocyclops leuckarti, Keratella cochlearis, Keratella quadrata, Asplanchna priodonta. Różnice pomiędzy ciężarami największych i najmniejszych osoboników były nawet kilkakrotne (tab. 5).

Zaobserwowano w rzecze Płoni dobowe zmiany liczebności wioślarek i widłonogów oraz brak takich zmian u naupliusów i wrotków. Zarówno na st. I jak i II więcej wioślarek i widłonogów występowało w okresie nocnym niż dziennym. Powyższe stwierdzenie odnosi się jednak tylko do ciepłego okresu roku i do dorosłych osobników. Młodociane skorupiaki zdradzały tendencję do liczniejszego występowania w okresie dziennym podczas całego roku. Późną jesienią i zimą również dorosłe osobniki Daphnia iBosmina przeważały w okresie dziennym.

Zooplanktcı wypływający z jeziora Płoń ulegał degradacji w dziesięciokilometrowym odcinku rzeki, pomiędzy jeziorami Płoń i Miedwie (tab. 8). Już w odległości $8 \mathrm{~km}$ od jez. Płoń doszło do prawie całkowitego ustąpienia z planktonu rzeki dużych skorupiaków - Daphnia i Mesocyclops oraz nauplius. W odległości $10 \mathrm{~km}$ od jeziora nastąpiła prawie dziesięciokrotna redukcja liczebności cał ego zooplanktonu oraz ośmiokrotne zmniejszenie jego biomasy. W przeciwieństwie do dużych skoru- 
piaków, nie stwierdzono w rẓece tak szybkiej redukcji liczebności wrotków (z wyjątkiem Asplanchna) oraz małej wioślarki Chydorus sphaericus. Główną przyczyną opisanej degradacji zooplanktonu w rzece było żerowanie narybku.

Б. Шляу эр

ЗООПЛАНКТОН, ВЫНОСИМЫЙ ИЗ ОЗЁР РЕКОЙ ПЛОНЬ

$P$ e 3 io $M$

В 1971-72 гг. исследовали зоопланктон реки Плонь на участке, расположенном вблизи её выхода из озера Плонь ( І опытный участок) и за озером Желевко (II опытный участок). Численность зоопланктона на I опытном участке была в среднем в 4 раза большей, а его биомасса - в 10 раз больше, чем на II опытном участке. Иными были также видовой состав и система доминантов на обоих участках (табл. 2 и 3 ).

Наиболее многочисленными ракообразными на, опытном участке были: Dap̄hnia longispina (максимальное их количество прихадилось на май - 236375 особей на м ${ }^{3}$ ), Bosmina coregoni coregoni (максимум в октябре - 64375 особей на м³), Chydorus sphaericus (максимум в августе - 505500 особей: на м ${ }^{3}$ ), Eudiaptomus gracilis (максимум в июне и октябре - по 9500 особей на м²), Mesocyclops leuckarti (максимум в августе - 241700 особей на м³), Сусlops (максимум в октябре и апреле - по 14000 особей на м $^{3}$ ), Общее максимальное количество зоопланктона приходилось на август (2 035500 особей на м ${ }^{3}$, табл. 2).

Самую больпую биомассу составляли на опытном участке ракообразные из рода Daphnia, Bosmina, Chydorus и веслоногий рачок Mesocyclops leuckarti. Наибольшую биомассу составлял зоопланктон в августе месяце $\left(11,289 \mathrm{\Gamma} / \mathrm{M}^{3}\right)$, минимум приходился на март месяц $\left(0,404 \mathrm{r} / \mathrm{m}^{3}\right)$. Среднегодовая биомасса составляла - 2,697 г./ ${ }^{3}$ воды (табл. 6).

Отмечены сезонные изменения размеров и видов: Bosmina coregoni coregoni, Eudiaptomus gracilis, Mesocyclops leuckarti, Keratella cochlearis, Keratella quadrata, Asplanchna priodonta. Разницы между весом самых крупных и самых мелких особей довольно значительными (табль. 5).

В p. Плонь замечены' суточные изменения численности веслоногих рачков, а также отсутствие таких изменений $\mathbf{y}$ науплиусов и коловраток. Как на I, так и на II участке больше всего веслоногих рачков было в ночное время. Вышесказанное касается, однако, только тёплого периода и только взрослых особей. Молодь ракообразных проявляла тенденцию к большей численности в дневное время в течение всего года. Позднен осенью и зимой взрослые особи Daphnia и Bosmina преобладали такще в дневное время. 
Зоопланктон, попадающй из оз. Плонь, подвергался деградации на десятикилометровом участке реки, междљ озёрами Плонь и Медве (табл. 8). Ужена расстоянии 8 км от оз. Плонь почти полностью исчезли из речного планктона крупные ракообразные Daphnia и Mesocyclops, а также науплиус. На расстоянии 10 км от озера наступила почти десятикратная редукция численности всего зоопланктона и восьмикратное уменьшение его биомассы. Что касается мелюих ракообразных, то столь быстрая редукция численности коловраток (за исключением Asplanchna) и мелкого рачка Chydorus sphaericus не отмечена. Основной причиной выпеупомянутой деградации зоопланктона в рөке был нагул молоди рыб.

Address:

Dr Zofia Sadowska Insty tut A kwakultury i Techniki Rybackiej AR

71-466 Szczecin, ul. Doktora Judyma 34

Polska - Poland 